Jahangirnagar University J. Biol. Sci. 7(1): 35-44, 2018 (June)

\title{
Effects of sodium chloride on germination and seedling growth of Sunflower (Helianthus annuus L.)
}

\author{
F.M. Tonmoy Chowdhury, M.A. Halim, Feroza Hossain and Nahid Akhtar \\ Plant Physiology and Biochemistry Laboratory, Department of Botany, \\ Jahangirnagar University, Savar, Dhaka-1342, Bangladesh
}

\begin{abstract}
The response of BARI Sunflower-2 (Helianthus annuus L.) to sodium chloride $(\mathrm{NaCl})$ at germination and early seedling growth was investigated. The seeds and seedlings of sunflower were treated with a series of eight different concentrations of $\mathrm{NaCl}$ viz 25, 50,75, 100, 125, 150, 175 and $200 \mathrm{mM}$ and distilled water (control) and were allowed to grow under plate culture condition. The results showed that the highest salinity concentration $(200 \mathrm{mM} \mathrm{NaCl})$ remarkably decreased the germination percentage, germination index and speed of germination of BARI Sunflower-2. Fresh and dry masses of both shoot and root were significantly reduced at a $25-200 \mathrm{mM} \mathrm{NaCl}$ solution. Significant reductions of shoot and root length were also noted with the increase of $\mathrm{NaCl}$ concentration. The results also illustrate that up to $50 \mathrm{mM} \mathrm{NaCl}$ concentration, all of the germination indices and fresh and dry biomass were withstand more than $70 \%$. Thus the present study concluded that the BARI Sunflower-2 could be cultivated in moderately saline soil.
\end{abstract}

Key words: Salinity, Germination percentage, Germination index, Germination speed.

\section{INTRODUCTION}

Sunflower is the most important oil seed crop of the world next to groundnut, rapeseed and mustard (Talia et al., 2011). Sunflower is a newly introduced oil seed crop in Bangladesh. Sunflower as a photo and thermo-neutral crop can be grown both in Rabi and Kharip seasons. It can fill up the gap between production and consumption of edible oil by expanding the area of sunflower production. A large portion of coastal area or southern parts of Bangladesh is now affected in sodium chloride salinity (Khatun et al., 2016). As a result the saline tolerant cultivar can be grown in this area at Rabi season when paddy land remain fallow. If any cultivar of sunflower would release as saline tolerant, it would be beneficial for our farmers as well as our country. Though its cultivation is lower due to increase of the rice producing area, it has bright future because of cropping intensity which is increasing gradually (Jahangir et al., 2006). In order to mitigate the problem of oil seed crisis, it is necessary to increase the oil seed production in our country.

Salinity is considered as a major abiotic stress and significant factor affecting crop production all over the world and especially in arid and semi-arid region (Davidson and Chevalier, 1987; Khajeh-Hosseni et al., 2003). The common salts normally present in saline soils are the chlorides, sulfates, bicarbonates, carbonates and borates of $\mathrm{Na}, \mathrm{K}, \mathrm{Ca}$ and $\mathrm{Mg}$. Soil salinity is characterized by high amounts of $\mathrm{Na}^{+}, \mathrm{K}^{+}, \mathrm{Ca}^{2+}, \mathrm{Mg}^{2+}$ and $\mathrm{Cl}^{-}$

*Corresponding author: E-mail: nahid_akhtar98@yahoo.com 
which inhibits growth and productivity of the plant due to accumulation of these salts in the root zone and affected the absorption of water and nutrient elements (Szabolcs, 1979). Salinity impairs seed germination, retards plant development and reduces crop yield. At the later stage salinity decreases crop yield by affecting crop growth and yield parameters (Munns \& Tester, 2008; Wu et al., 2015). Salinity affects plant growth by distributing water relation, creating water imbalance in plant nutrition and affecting plant physiological and biochemical processes (Yeo et al., 1985; Campos et al., 1989; Bethke et al., 1992 and Karim et al., 1993).

Seed germination is one of the most fundamental and vital phases in the growth cycle of plants that determine plant establishment and the yield of the crops. Salinity have manyfold effects on the germination process: it alters the imbibition of water by seeds due to lower osmotic potential of germination media (Khan \& Weber, 2008), causes toxicity which changes the activity of enzymes of nucleic acid metabolism (Gomes-Filho et al., 2008), alters protein metabolism (Yupsanis et al.,1994 ; Dantas et al., 2007), disturbs hormonal balance (Khan and Rizvi, 1994), and reduces the utilization of seed reserves (Promila \& Kumar, 2000 ; Othman et al., 2006).

The current study was undertaken to investigate the effect of sodium chloride on germination percentage, germination index, germination speed, shoot and root length along with biomass of BARI Sunflower-2.

\section{MATERIALS AND METHODS}

Seeds of Sunflower, cultivar BARI Sunflower-2 (Helianthus annuus L.) were collected from Bangladesh Agricultural Research Institute (BARI) and were used as plant material. On the basis of previous research information (Carbonell-Barrachina and BurloCarbonell, 1997) eight different concentrations of $(\mathrm{NaCl})$ solution viz $25,50,75,100$, $125,150,175$ and $200 \mathrm{mM}$ and distilled water as control were used as treatment. In each treatment, $10 \mathrm{ml}$ of $\mathrm{NaCl}$ solution was applied per petridish. No Nutrient solution was applied in petridish. The germination experiment was carried out in the Plant Physiology and Plant Biochemistry laboratory of Botany Department, Jahangirnagar University, Savar, Dhaka.

For germination experiment 25 seeds based on seed uniformity were placed on moist blotting paper in $9 \mathrm{~cm}$ diameter petridishes covered with a lid. The petridishes were kept under laboratory conditions where temperature fluctuated between $23-25^{\circ} \mathrm{C}$. The treatment solutions were applied separately for each petridish regularly. The number of seeds that were germinated was recorded at 24 hours interval for 7 days. After seven days of growth germination percentage, germination index, germination speed, shoot and root length, and fresh weight and dry weight of root and shoot were recorded.

The germination percentage, germination index and speed of germination was calculated by the following formula: 


$$
\text { Germination Percentage }(\text { GP })=\frac{\text { No. of germinated seeds }}{\text { Total no. of seed }} \times 100
$$

The germination index was calculated after final germination by the following equation (Karim et al., 1992)

$$
\text { Germination Index }(\mathbf{G I})=\frac{\text { Germination \% in each treatment }}{\text { Germination \% in the control }} \times 100
$$

Speed of germination was calculated according to Mohammed et al., 1989 by the following equation

$$
\text { Speed of Germination }(\mathbf{S G})=\frac{\text { No. of Seedlings }}{\text { First count on day } 1}+--+\frac{\text { No. of Seedlings }}{\text { Final count on day } 7}
$$

Seedling height and root lengths were recorded on the $7^{\text {th }}$ day after the seeds were placed for germination. At harvest on $7^{\text {th }}$ day, the seedlings were kept in oven and dried at $72^{\circ} \mathrm{C}$ until they reached a constant weight. Data on germination behavior and seedlings characteristics for each $\mathrm{NaCl}$ treatment were compared with those in the control treatment. The experiment was arranged out in randomized block design with three replications. The data recorded on different parameters were statistically analyzed with the help of Microsoft Excel 2013 and Duncan multiple range test (DMRT) was done by using SPSS Program 16.00. The difference (LSD) level of significance was also found out after performing ANOVA.

\section{RESULTS AND DISCUSSION}

Germination Percentage (GP) and Germination index (GI): In the present study, the highest germination percentage was recorded $90 \%$ in the control and the lowest value was $53.33 \%$ in $200 \mathrm{mM} \mathrm{NaCl}$ (Table 1). The moderate germination percentages were recorded $76.67 \%, 73.34 \%, 70.00 \%$ and $66.67 \%$ in $25,50,75,100$ and $125 \mathrm{mM} \mathrm{NaCl}$ levels respectively. The germination index (GI) was significantly decreased as the $\mathrm{NaCl}$ levels were increased. The highest germination index was 100.00 in the control and lowest 59.26 in $200 \mathrm{mM} \mathrm{NaCl}$ (Table 1). The moderate germination indices were 85.20, 81.49, 77.78 and 74.08 in $25,50,75,100$ and $125 \mathrm{mM}$ of $\mathrm{NaCl}$ levels. The result agrees with the work of Karim et al. (1992) and Mondal et al. (1988) that salinity delays germination. This result was in similar with Francois et al. (1986) noticed that in wheat germination was significantly delayed and the final germination percentage was markedly reduced by salinity.

The mean values of germination percentages and germination indices of BARI Sunflower-2 are presented in Table 1 which show a decreasing tendency of the germination percentage and germination index with the increase of $\mathrm{NaCl}$ concentration. 
Germination percentage of a crop is considered as the most important criteria for a successful crop establishment under stress conditions because under saline conditions germination is the first stage of a crop exposed to salinity. Usually a crop with high germination percentage and GI performs well under saline conditions than with low GI. Presumably the osmotic effect due to salinity on inhibition of seeds was the main cause for the reduction of germination percentage and varieties differences for GI as indicated by Akbar and Ponnamperuma (1982) and Uhvits (1946). The negative effect of salinity on seed germination might be happened due to salinity-induced ionic imbalance or toxicity (Panuccio et al., 2014).

Speed of Germination (SG): The highest germination speed was obtained 3.77 (100\%) at the control and the lowest was $0.76(20.16 \%)$ at $200 \mathrm{mM} \mathrm{NaCl}$ (Table 1). In the present study at $125 \mathrm{mM}$ of $\mathrm{NaCl}$ salinity, the germination speed was $71.09 \%$ which is an indication of salt tolerance (Halim et al., 2004). The speed of germination was decreased with the increase of $\mathrm{NaCl}$ concentrations (Table 1). The decreasing tendency of the speed of germination due to salinity was in conformity with the reports of others (Muhammad et al., 1986; Khan et al., 1997). The SG is an indicative of crop performance under saline conditions. The speed of germination may have decreased due to inactivation of hydrolase enzymes at the germination stage of seeds at high concentrations of $\mathrm{NaCl}$ salinity (Maas \& Hoffman, 1977; Blum, 1988).

Table 1. Effect of different levels of salinity on germination percentage, germination index and germination speed of BARI Sunflower-2

\begin{tabular}{c|c|c|c}
\hline $\begin{array}{c}\text { Treatments } \\
\text { NaCl }(\mathbf{m M})\end{array}$ & $\begin{array}{c}\text { Germination } \\
\text { percentage }\end{array}$ & $\begin{array}{c}\text { Germination } \\
\text { index }\end{array}$ & $\begin{array}{c}\text { Germination } \\
\text { speed }\end{array}$ \\
\hline Control & $90.00 \mathrm{a}$ & $100.00 \mathrm{a}$ & $3.77 \mathrm{a}$ \\
25 & $76.67 \mathrm{~b}$ & $85.20 \mathrm{~b}$ & $3.30 \mathrm{~b}$ \\
& & & $(87.53)$ \\
50 & $73.34 \mathrm{bc}$ & $81.49 \mathrm{c}$ & $3.17 \mathrm{~b}$ \\
& & $84.08)$ \\
& & $77.78 \mathrm{~d}$ & $1.27 \mathrm{c}$ \\
75 & $70.00 \mathrm{bc}$ & $74.08 \mathrm{e}$ & $(33.69)$ \\
& & & $1.17 \mathrm{~d}$ \\
100 & $66.67 \mathrm{bc}$ & $74.08 \mathrm{e}$ & $(31.03)$ \\
& & & $1.09 \mathrm{e}$ \\
125 & $66.67 \mathrm{bc}$ & $70.38 \mathrm{f}$ & $(28.91)$ \\
& & & $1.05 \mathrm{e}$ \\
150 & $63.34 \mathrm{bc}$ & $66.67 \mathrm{~g}$ & $(27.85)$ \\
& & & $1.03 \mathrm{e}$ \\
175 & $60.00 \mathrm{~cd}$ & $59.26 \mathrm{~h}$ & $(27.32)$ \\
& & & $0.76 \mathrm{f}$ \\
200 & $53.33 \mathrm{~d}$ & 76.55 & $(20.16)$ \\
& & 0.47 & 1.85 \\
\hline Cultivar Mean & 68.89 & 11.88 & 0.26 \\
\hline LSD $(5 \%)$ & 0.64 & & 36.46 \\
\hline CV\% & 17.23 & &
\end{tabular}

- Data expressed as mean values of 3 replicates.

- In a column followed by same letters do not differ significantly at 5\% level of significance.

- Values within parentheses indicate percent change over control. 
Shoot and root length: At the highest level of salinity $(200 \mathrm{mM})$ the shoot length decreased up to $6.5 \mathrm{~cm}$ whereas in the control the shoot length was found $14 \mathrm{~cm}$. Shoot length was found $75 \%$ compared to the control at $50 \mathrm{mM} \mathrm{NaCl}$ salinity whereas the lowest shoot length $46.42 \%$ was exhibited compared to the control at the highest level of $\mathrm{NaCl}$ treatment (Table 2). The decreasing tendency of shoot growth from $50 \mathrm{mM}$ to 150 $\mathrm{mM}$ was slow. It indicated that at least $65 \%$ growth rate remained at $150 \mathrm{mM} \mathrm{NaCl}$ salinity treatment but drastic reduction was observed at $200 \mathrm{mM}$. Reduction of shoot length is a common phenomenon of many crop plants under saline conditions as noticed earlier by several workers (Javed \& Khan, 1975; Amin et al., 1996). Under saline condition plant suffers from osmotic stress. To adjust osmotically the plant has to synthesize compatible metabolites and thus need extra energy. For this reason the growth processes suffer considerably (Taiz and Zaiger, 1991). Karim et al. (1992) pointed out that shoot growth was more sensitive to salinity than germination and root growth.

Table 2. Effect of different levels of salinity on shoot and root length $(\mathrm{cm})$ of BARI Sunflower-2

\begin{tabular}{c|c|c}
\hline Treatments & Shoot length & Root length \\
NaCl $(\mathbf{m M})$ & & $13.00 \mathrm{a}$ \\
\hline Control & $14.00 \mathrm{a}$ & $12.67 \mathrm{a}$ \\
25 & $11.84 \mathrm{~b}$ & $(97.46)$ \\
& $(84.57)$ & $12.33 \mathrm{a}$ \\
50 & $10.50 \mathrm{bc}$ & $(94.85)$ \\
& $(75.00)$ & $11.67 \mathrm{ab}$ \\
& $10.33 \mathrm{bc}$ & $(89.76)$ \\
15 & $(73.79)$ & $10.50 \mathrm{ab}$ \\
& $9.33 \mathrm{c}$ & $(80.76)$ \\
125 & $(66.64)$ & $9.10 \mathrm{bc}$ \\
& $9.17 \mathrm{c}$ & $(70.00)$ \\
150 & $(65.50)$ & $8.84 \mathrm{bc}$ \\
& $9.13 \mathrm{c}$ & $(68.00)$ \\
175 & $(65.22)$ & $7.17 \mathrm{c}$ \\
& $6.50 \mathrm{~d}$ & $(55.16)$ \\
200 & $(46.42)$ & $7.17 \mathrm{c}$ \\
& $6.50 \mathrm{~d}$ & $(55.16)$ \\
Cultivar Mean & $(46.42)$ & 10.84 \\
\hline LSD $(5 \%)$ & 9.70 & 1.46 \\
CV\% & 0.76 & 22.38 \\
\hline
\end{tabular}

- Data expressed as mean values of 3 replicates.

- In a column followed by same letters do not differ significantly at $5 \%$ level of significance.

- Values within parentheses indicate percent change over control.

The mean value of root length decreased significantly with the increase in salinity levels (Table 2). At the highest level of salinity $(200 \mathrm{mM})$ the root length was $7.17 \mathrm{~cm}$ and in the control the root length was $13 \mathrm{~cm}$. Root length was observed $80 \%$ compared to the control at $100 \mathrm{mM} \mathrm{NaCl}$ salinity. At $200 \mathrm{mM} \mathrm{NaCl}$ salinity root growth was decreased by $55.16 \%$ compared to the control while maximum root growth was found at control 
treatment. Root growth was suppressed by salinity. The results of this experiment are in similar with the findings of Cramer et al. (1988) and Ashraf et al. (2005). Under saline conditions roots play an important role by excluding Na salt or by controlling easy pass of the $\mathrm{Na}$ to the shoot (Karim et al., 1992; Amin et al., 1996). Moreover the longer roots have an advantage for absorbing higher amount of water than shorter roots.

Table 3. Effect of different levels of salinity on fresh weight of shoot and root (gm/ plant) of seedling of BARI Sunflower-2

\begin{tabular}{ccc}
\hline $\begin{array}{c}\text { Treatments } \\
\text { NaCl }(\mathbf{m M})\end{array}$ & Fresh weight of shoot & Fresh weight of root \\
\hline Control & $1.25 \mathrm{a}$ & $0.69 \mathrm{a}$ \\
\hline 25 & $1.16 \mathrm{a}$ & $0.46 \mathrm{~b}$ \\
& $(92.8)$ & $(66.67)$ \\
\hline 50 & $0.92 \mathrm{ab}$ & $0.41 \mathrm{bc}$ \\
& $(73.60)$ & $(59.42)$ \\
\hline 75 & $0.73 \mathrm{~b}$ & $0.38 \mathrm{c}$ \\
& $(58.40)$ & $(55.07)$ \\
\hline 100 & $0.69 \mathrm{~b}$ & $0.31 \mathrm{~d}$ \\
& $(55.20)$ & $(44.90)$ \\
\hline 125 & $0.65 \mathrm{~b}$ & $0.31 \mathrm{~d}$ \\
& $(52.00)$ & $(44.90)$ \\
\hline 150 & $0.64 \mathrm{~b}$ & $0.27 \mathrm{~d}$ \\
& $(51.20)$ & $(39.13)$ \\
\hline & $0.19 \mathrm{c}$ & $0.06 \mathrm{e}$ \\
& $(15.20)$ & $(8.69)$ \\
\hline & $0.18 \mathrm{c}$ & $0.06 \mathrm{e}$ \\
& $(14.40)$ & $(8.69)$ \\
\hline & 0.71 & 0.33 \\
\hline & 0.60 & 0.28 \\
\hline & 55.80 & 57.78 \\
\hline Cultivar Mean & Values within parentheses indicate percent change over control. & \\
\hline
\end{tabular}

Biomass (Seedling Fresh weight and Dry weight of BARI Sunflower-2): In the present study, plant biomass decreased markedly with the increasing level of sodium chloride concentration, which contradict the result of Carbonell-Barrachina et al. (1997). The shoot fresh weight decreased significantly with the increasing level of salinity (Table 3 ).

At the highest level of salinity $(200 \mathrm{mM})$ the shoot fresh weight was $0.18 \mathrm{gm}$ and in the control the shoot fresh weight was $1.25 \mathrm{gm}$ after seven days. Fresh weight of shoot was reduced $26.40 \%$ at $50 \mathrm{mM} \mathrm{NaCl}$ salinity whereas up to $200 \mathrm{mM}$ it was reduced to $85.60 \%$. This may be due to diversion of energy in the process of osmotic adjustment. Results obtained from this study are in confirmation with the findings of Ashraf \& Leary (1997). 
The root fresh weight decreased significantly with the increasing level of salinity (Table $3)$. At the highest level of salinity $(200 \mathrm{mM})$ the root fresh weight was $0.06 \mathrm{gm}$ and in the control the root fresh weight was $0.69 \mathrm{gm}$. The highest salinity level $(200 \mathrm{mM} \mathrm{NaCl})$ was drastically reduced root fresh weight by $91.31 \%$, while at slightly salinity level $(25 \mathrm{mM}$ $\mathrm{NaCl}$ ), it was $66.67 \%$. Results obtained from the experiment clearly indicates that root fresh weight also decreased with the increasing $\mathrm{NaCl}$ levels. This may be due to diversion of energy in the process of osmotic adjustment. The results are in confirmation with the findings of Ashraf \& Leary (1997).

The shoot dry weight decreased significantly with the increasing level of salinity (Table 4). At the highest level of salinity $(200 \mathrm{mM})$ the shoot dry weight was $0.08 \mathrm{gm}$ and in the control the shoot dry weight was $0.39 \mathrm{gm}$. High concentration $(200 \mathrm{mM} \mathrm{NaCl})$ of $\mathrm{NaCl}$ led to significant reduction of shoot dry mass by $79.49 \%$, while at $50 \mathrm{mM} \mathrm{NaCl}$ it was $71.20 \%$. The results are in similar with the findings of Cramer et al. (1994), Halim et al. (2004) and Mansour et al. (2005). Shoot dry weight was decreased by salinity. Shoot dry weight at seedling stage is an indication of seedling vigour. Under saline conditions the variety with higher shoot mass performs better than a variety with lower shoot mass (Blum, 1988; Karim et al., 1992).

Table 4. Effect of different levels of salinity on dry weight of shoot and root (gm/plant) of seedling of BARI Sunflower-2

\begin{tabular}{c|c|c}
\hline Treatments & Dry weight of shoot & Dry weight of root \\
NaCl $(\mathbf{m M})$ & & \\
\hline Control & $0.39 \mathrm{a}$ & $0.57 \mathrm{a}$ \\
25 & $0.34 \mathrm{a}$ & $0.52 \mathrm{~b}$ \\
& $(87.18)$ & $(91.22)$ \\
50 & $0.28 \mathrm{~b}$ & $0.38 \mathrm{c}$ \\
& $(71.20)$ & $(66.67)$ \\
& $0.25 \mathrm{bc}$ & $0.34 \mathrm{c}$ \\
15 & $(64.10)$ & $(59.64)$ \\
& $0.22 \mathrm{c}$ & $0.29 \mathrm{~d}$ \\
& $(56.41)$ & $(50.87)$ \\
& $0.16 \mathrm{~d}$ & $0.27 \mathrm{~d}$ \\
150 & $(41.02)$ & $(47.36)$ \\
& $0.15 \mathrm{~d}$ & $0.17 \mathrm{e}$ \\
175 & $(38.46)$ & $(29.82)$ \\
& $0.08 \mathrm{e}$ & $0.11 \mathrm{f}$ \\
200 & $(20.51)$ & $(19.29)$ \\
& $0.08 \mathrm{e}$ & $0.10 \mathrm{f}$ \\
Cultivar Mean & $(20.51)$ & $(17.54)$ \\
LSD $(5 \%)$ & 0.22 & 0.31 \\
CV\% & 0.18 & 0.27 \\
\hline
\end{tabular}

- Data expressed as mean values of 3 replicates.

- In a column followed by same letters do not differ significantly at $5 \%$ level of significance.

- Values within parentheses indicate percent change over control. 
The root dry weight decreased significantly with the increasing level of salinity (Table 4). At the highest level of salinity $(200 \mathrm{mM})$ the root dry weight was $0.10 \mathrm{gm}$ and in the control the root dry weight was $0.57 \mathrm{gm}$. Dry weight of root was observed $50.87 \%$ at 100 $\mathrm{mM} \mathrm{NaCl}$ salinity and up to $200 \mathrm{mM} \mathrm{NaCl}$ salinity dry weight of root reduced to $82.46 \%$. The results are in similar with the findings of Akram et al. (2007) reported that root dry weight of all corn hybrids showed a decline towards increase in salinity level. Root dry weight decreased with the increase in the salinity levels. Usually higher fresh weight of root is an indication of higher root dry weight. Usually tolerant variety possess higher root mass compared to salt susceptible variety.

This study showed that at least $65 \%$ shoot growth rate was sustained up to $150 \mathrm{mM} \mathrm{NaCl}$ salinity treatment but drastic reduction $(46.42 \%)$ was found at $200 \mathrm{mM}$. Moreover, more than $50 \%$ dry weight of shoot and root at $100 \mathrm{mM} \mathrm{NaCl}$ salinity treatment was found. These results of this study indicate that the seedlings of BARI Sunflower-2 could be withstand up to moderate salinity level. This findings will be helpful for further experiments to determine the physiological consequences on salt tolerant and salt susceptible cultivars at seedling stages.

\section{REFERENCES}

Akbar, M. and Ponnamperuma, F.N. 1982. Saline soils of South and Southeast Asia as a potential rice lands. In: Rice Research Strategies for the future, IRRI, Los Banos, Laguna. Philippines. pp. 265-281.

Akram, M., Asghar, M.M. Yasın, A.M. Farrukh, S.M. and Hussain, M. 2007. Competitive seedling growth and $\mathrm{K}^{+} / \mathrm{Na}^{+}$ratio in different maize (Zea mays L.) hybrids under salinity stress. Pak. J. Bot. 39(7): 2553-2563.

Amin, M.A., Hamid, M.I., Islam and Karim, M.A. 1996. Root and shoot growth of rice cultivars in response to salinity. Agron. J. 6: 41-46.

Ashraf, M. and O' Leary, J.W. 1997. Responses of a salt tolerant and a salt sensitive line of sunflower to varying sodium/ calcium ratios in saline sand culture. J. Plant Nutr. 20: 361367.

Ashraf, M.Y., Akhtar, K., Sarwar, G. and Ashraf, M. 2005. Role of rooting system in salt tolerance potential of different guar accessions. Agron. Sust. Dev. 25: 243-249.

Bethke, P.C. and Drew, M.C. 1992. Stomatal and non stomatal components to inhibition of photosynthesis in leaves of Capsicum annum during progressive to $\mathrm{NaCl}$ salinity. Plant Physiol. 99: 219-226.

Blum, A. 1988. Salinity resistance. In: Plant Breeding for Stress Environments. CRC press (Florida). pp. 163-176.

Campos, I.S., Ferreira, I.G. and Assun, M.V. 1989. Salinity effects on growth and development of rice, physiological changes, Efeitos salinos no crescimento edesenvolvimento do arroz; altera $\mathrm{C}_{3} \mathrm{O}_{2}$ es fisiologicas. Pesquisa Agropecuaria Brashileira. 24: 1111-1118.

Carbonell-Barrachina, A.A. and Burlo-Carbonell, F. 1997. Effect of sodium arsenite and sodium chloride on bean plant nutrition (macronutrients). J. Plant Nutr. 20(11): 1617-1633.

Cramer, G.R., Alberico, G.J. and Schmidt, C. 1994. Leaf expansion limits dry matter accumulation of salt-stressed maize. Aust. J. Plant Physiol. 21: 663-674. 
Effects, sodium chloride, germination, seedling growth, Sunflower (Helianthus annuus L.)

Cramer, G.R., Epstein, E. and Läuchli, A. 1988. Kinetics of root elongation of maize in response to short term exposure to $\mathrm{NaCl}$ and elevated calcium concentration, J. Exp. Bot. 39:15131522.

Dantas, B.F., De Sa Ribeiro, L. and Aragao, C.A. 2007. Germination, initial growth and cotyledon protein content of bean cultivars under salinity stress. Rev. Bras de Sementes. 29: 106-110.

Davidson, D.J. and Chevalier, P.M. 1987. Influence of polyethylene glycol induced water deficits on tiller production in spring wheat. Crop Sci. 27: 1185-1187.

Francois, L.E., Maas, E.V. Donovan, T.J. and Youngs, V.L. 1986. Effect of salinity on grain yield and quality, vegetative growth and germination of semi-dwarf durum wheat. Agron. J. 78: 1053-1058.

Gomes-Filho, E., Machado Lima, C.R.F. Costa, J.H. da Silva, A.C. da Guia Silva Lima, M. de Lacerda, C.F. and Prisco, J.T. 2008. Cowpea ribonuclease: properties and effect of NaClsalinity on its activation during seed germination and seedling establishment. Plant Cell Rep. 27: 147-157.

Halim, M.A., Feroza Hossain, Meher Nigar and Nahid Akhtar. 2004. Effect of sodium chloride salinity on germination and early seedling stage of ten cultivars of rice. Bangladesh J. Life Sci. 16(1): 79-83.

Jahangir, A.A., Mondal, R. K. Katrun Nada, Sadia Afroze, R. and Hakim, M.A. 2006. Response of Nitrogen and Phosphorus Fertilizer and Plant Spacing on Growth and Yield Contributing Character of Sunflower. Bangladesh J. Sci. Ind. Res. 41(1-2): 33-40.

Javed, A.S. and Khan, M.F.A. 1975. Effect of sodium chloride and sodium sulphate on IRRI rice. J. Agric. Res. (Punjab), 13: 705-710.

Karim, M.A., Nawata, E. and Sigenaga, S. 1993. Effects of Salinity and Water stress on the growth, yield and physiological characteristics in hexaploid triticale. Jpn. J. Trop. Agric. 37: 46-52.

Karim, M.A.N., Utsunomiya and Shigenaga, S. 1992. Effect of sodium chloride on germination and growth of hexaploid triticale at early seedling stage. Jpn. J. Crop Sci. 61: 279-284.

Khajeh-Hosseini, M., Powell, A.A. and Bimgham, I.J. 2003. The interaction between salinity stress and seed vigor during germination of soybean seeds. Seed Sci. Technol. 31: 715-725.

Khan, M.A. and Rizvi, Y. 1994. Effect of salinity, temperature and growth regulators on the germination and early seedling growth of Atriplex griffithii var. Stocksii. Can. J. Bot. 72: 475-479.

Khan, M.A. and Weber, D.J. 2008. Ecophysiology of high salinity tolerant plants (tasks for vegetation science), 1st edn. Springer, Amsterdam.

Khan, M.S.A., Hamid, A. Salauddin, A.B.M. Quasem, A. and Karim, M.A. 1997. Effect of sodium chloride on Growth, Photosynthesis and Mineral Ions Accumulation of Different Types of Rice (Oryza sativa L.) J. Agron. Crop Sci. 179: 149-161.

Khatun, M., Tanvir, M. B. Hossain, M. A. Monayem miah, Khandoker, S. and Rashid, M.A. 2016. Profitability of Sunflower Cultivation in some selected sites of Bangladesh. Bangladesh J. Agr. Res. 41(4): 599-623.

Maas, E.V. and Hoffman, G.J. 1977. Crop salt tolerance: Current assessment. J. Irrig. Drainage Div. ASCE. 103: 115-134.

Mansour, M.M.F., Salama, K.H.A. Ali, F.Z.M. and Abou Hadid, A.F. 2005. Cell and plant responses to $\mathrm{NaCl}$ in Zea mays L. cultivars differing in salt tolerance. Gen. Appl. Plant Physiol. 31(1-2): 29-41.

Mohammed, R.M., Campbell, W. F. and Rumbaugh, M.D. 1989. Variation in salt tolerance of alfalfa. Arid Soil Res. 3: 11-20.

Mondal, T.K., Bal, A.R. and Dal, S. 1988. Effect of salinity on germination and seedling growth of different rice (Oryza sativa L.) cultivars. J. Indian Soc. Coastal Agri. Res. 6: 91-97. 
Muhammad, S., Neve, H.U and Mendoza, B.S. 1986. Effect of gypsum on the growth and mineral nutrition of some efficient rices in coastal saline sodic soils. Paper presented at the $2^{\text {nd }}$ annual meeting of the ECSSP. Benguet Stato University, La Trinidad, Bengust. P.28.

Munns, R. and Tester, M. 2008. Mechanisms of Salinity Tolerance. Annual Review of Plant Biology. 59: 651-681.

Othman, Y., Al-Karaki, G. Al-Tawaha, A.R. and Al-Horani, A. 2006. Variation in germination and ion uptake in barley genotypes under salinity conditions. World J. Agric. Sci. 2: 11-15.

Panuccio, M.R., Jacobsen, S.E. Akhtar, S.S. and Muscolo, A. 2014. Effect of saline water on seed germination and early seedling growth of halophyte quinoa. AOB plants. 6: plvo47.

Promila, K. and Kumar, S. 2000. Vigna radiata seed germination under salinity. Biol. Plant. 43 : 423-426.

Szabolcs, I. 1979. Review of Research on Salt Affected Soils. Paris, pp. 9-10.

Taiz, I. and Zeiger, E. 1991. Plant Physiology. The Benjamia and Cummings Publication Co. Inc. California. pp. 362-364.

Talia, P., Greizerstein, E.J. Hopp, H.E. Paniego, N. Poggio, L. and Heinz, R.A. 2011. Detection of single copy sequences using BAC-FISH and C-PRINS techniques in sunflower chromosomes. Biocell. 35: 19-28.

Uhvits, R. 1946. Effect of osmotic pressure on water absorption and germination of alfalfa seeds. Amer. J. Bot. 33: 278-285.

$\mathrm{Wu}, \mathrm{G}$. Q., Jiao, Q. and Shui, Q. Z. 2015. Effect of salinity on seed germination, seedling growth and inorganic and organic solutes accumulation in sunflower (Helianthus annuus L.). Plant, Soil and Environment. 61: 220-226.

Yeo, A.R., Capron, S.J.M. and Flowers, T.J. 1985. The effect of Salinity upon Photosynthesis in rice (Oryza sativa L.) gas exchange by individual leaves in relation to their salt content. $J$. Exp. Bot. 36: 1240-1248.

Yupsanis, T., Moustakas, M. and Domiandou, K. 1994. Protein phosphorylationdephosphorylation in alfalfa seeds germinating under salt stress. J. Plant Physiol. 143: 234 240 . 